\title{
Apples and Pears: Calendar of Operations for Home Gardeners
}

\author{
Pamela M. Geisel is UC Cooperative Extension Farm Advisor in Environmental Horticulture for \\ Fresno County; Carolyn L. Unruh is UCCE staff writer for Fresno County; and Paul Vossen is \\ UCCE Farm Advisor in Fruits, Vegetables, and Marketing for Sonoma and Marin Counties.
}

Apple and pear trees do best in climates that have at least 1,000 hours of winter chilling below $45^{\circ} \mathrm{F}$ and moderate summer temperatures. They are available on an assortment of rootstocks that provide a wide range of vigor and size control. Some varieties set an adequate crop without the presence of a cross-pollinating variety, but others do not. Be sure to check the cross-pollination requirements for each variety that you plant.

\section{Winter Dormant Season}

- Plant new trees during the dormant season.

- With few exceptions, areas with adequate chilling for apples and pears also have sufficient winter rainfall to maintain adequate soil moisture. However, if rainfall is below normal, irrigate the trees once during the winter, allowing the water to soak to a depth of 2 to 3 feet to encourage deep rooting.

- Prune out 15 to 20 percent of last year's growth to let light into the tree center. Remove broken, drooping, crossed, or diseased limbs, as well as water sprouts and root suckers. Spur-prune Asian pears to a length of three buds.

- If scale insects, aphids, or mites cause recurring problems, follow the label instructions to apply a dormant oil spray to control these pests.

- Paint trunks and lower branches of young or non-vigorous trees with a 1:1 mixture of white interior latex paint and water to prevent sunburn injury during summer. Apply the paint mixture from two inches below the soil surface to two feet above.

- Rake and remove all fallen leaves to help control apple scab and powdery mildew.

\section{Spring Bloom Season}

- To help prevent powdery mildew, spray trees with a fungicide such as calcium polysulfide (liquid lime-sulfur) or wettable sulfur. Apply first at the green-tip stage (when you can see a pale green color in the swelling buds at the tips of spurs) and again at the pink bud stage (when the flower buds have taken on a pink hue and are just about to open), and then repeat at 10-day intervals until rains stop.
- Fireblight is a serious bacterial disease of pears and apples. To control, prune out infected limbs, making your pruning cuts in healthy wood at least 12 inches below the dead portion of the branch. Remove and destroy all diseased wood. A spray application of fixed copper every five days during bloom may help control the disease, although copper causes russetting on some apple and pear varieties.

- Control of codling moth (worms in ripening fruit) must begin in spring, shortly after petal fall, and may require repeated applications of insecticides. For specific information on timing, recommended insecticides, and alternative pest management techniques, see the UC IPM Pest Note on Codling Moth (http: / / www.ipm. ucdavis.edu). One suggested method to reduce codling moth damage without spraying is to bag the fruit after it has been thinned. Cut a small hole in the bottom of a brown paper lunch sack and slip the hole over a small developing fruit. Staple the mouth of the bag shut to exclude adult moths.

- Fertilize trees before the first spring irrigation. Apply fertilizer to young trees twice (in May and July); use about 4 to 8 ounces of ammonium sulfate at each application. Large, mature trees should receive about 4 pounds of ammonium sulfate over the course of the growing season. Other fertilizers should be applied according to label recommendations.

- When fruit of red apple varieties is $3 / 4$ inch in diameter, thin the fruit to one fruit every 6 inches of shoot growth or one fruit per cluster. Yellow and green apple varieties generally produce well if thinned to two fruit per cluster. This helps increase fruit size and reduce damage from codling moths.

- Pears are not usually thinned. However, the Asian pear varieties are an exception. They are thinned twice: once just after bloom to reduce alternate bearing and once 30 to 60 days after bloom to increase fruit size. The final crop of Asian pears should be spaced 5 to 7 inches apart on the branch. 


\section{Summer Growing Season}

- If you use drip irrigation, apply just the amount of water needed to replace what is used by the tree and lost from the soil through evaporation. If you use sprinkler or flood irrigation, water about every two to three weeks and provide enough water to wet the soil to a depth of 18 to 24 inches. Young, small trees will need about 4 to 12 gallons of water per day, and large trees will need as much as 200 gallons per week during the hottest summer months, July and August. Water requirements will vary depending on environmental conditions and your soil type. Irrigate at the drip line, well away from the trunk of the tree.

- Discard any overripe or fallen fruit to reduce new generations of pests such as codling moths.

- Harvest when fruit is fully mature and has full color. Lift apples up and back over the spur to remove them, rather than pulling down on the fruit.

- Pears vary in terms of when they are harvested. European pears, such as the Bartlett, are harvested when green and hard and stored at $32^{\circ} \mathrm{F}$. Then they are allowed to soften at room temperature. Asian pears are allowed to ripen on the tree. All pears are harvested by gently lifting up the fruit until it separates from the spur. Do not twist or pull.

\section{Autumn}

- Continue regular irrigation until fall rains and cold weather arrive.

- Pick up all fallen leaves to lessen the potential for apple scab infection in the following season. To reduce overwintering pests, clean up all fallen fruit and any overripe fruit still remaining on the tree.

\section{For More Information}

Cousult these UC IPM Pest Notes online at http: / / www.ipm.ucdavis.edu:

$$
\begin{aligned}
& \text { Apple Scab } \\
& \text { Bordeaux Mixture } \\
& \text { Codling Moth } \\
& \text { Fire Blight } \\
& \text { Powdery Mildew }
\end{aligned}
$$

You'll also find detailed information on many aspects of fruit and nut tree care in these titles and in other publications, slides sets, and videos from UC ANR:

California Master Gardener Handbook, publication 3382

Drip Irrigation in the Home Landscape, publication 21579

Pests of the Garden and Small Farm, publication 3332

Pruning Fruit and Nut Trees, publication 21171

Sweet Cherries for the Home Grounds, publication 2951

The UC Guide to Solving Garden and Landscape Problems, CD-ROM 3400

\section{ORDERING}

To order these products, visit our online catalog at http: / / anrcatalog.ucdavis.edu. You can also place orders by mail, phone, or fax, or request a printed catalog of publications, slide sets, and videos from

University of California

Agriculture and Natural Resources

Communication Services

6701 San Pablo Avenue, 2nd Floor

Oakland, California 94608-1239

Telephone: 800-994-8849 or 510-642-2431

FAX: 510-643-5470

E-mail inquiries: danrcs@ucdavis.edu

For a free catalog of other publications, telephone (800) 994-8849.

Visit the ANR Communication Services website at http: / / anrcatalog.ucdavis.edu.

Publication 7258

(C) 2002 by the Regents of the University of California,Division of Agriculture and Natural Resources.All rights reserved. 
The University of California prohibits discrimination against or harassment of any person employed by or seeking employment with the University on the basis of race, color, national origin, religion, sex, physical or mental disability, medical condition (cancer-related or genetic characteristics), ancestry, marital status, age, sexual orientation, citizenship, or status as a covered veteran (special disabled veteran, Vietnam-era veteran or any other veteran who served on active duty during a war or in a campaign or expedition for which a campaign badge has been authorized).

University Policy is intended to be consistent with the provisions of applicable State and Federal laws. Inquiries regarding the University's nondiscrimination policies may be directed to the Affirmative Action/Staff Personnel Services Director, University of California, Agriculture and Natural Resources, 300 Lakeside Drive, 6thFloor, Oakland, CA 94612-3550; 510-987-0096. For information on how to obtain this publication and other ANR CS products, call 800-994-8849.

pr-1/02-JWC/CY

ISBN 978-1-60107-049-4

This publication has been anonymously peer reviewed for technical accuracy by University of California scientists and other qualified professionals. This review process was managed by the ANR Associate Editor for Pomology, Viticulture, and Subtropical Horticulture.

\section{WARNING ON THE USE OF CHEMICALS}

Carefully follow all precautions and safety recommendations given on the container label. Store all chemicals in their original labeled containers in a locked cabinet or shed, away from foods or feeds, and out of the reach of children, unauthorized persons, pets, and livestock.

Confine chemicals to the property being treated. Avoid drift onto neighboring properties, especially gardens containing fruits and/or vegetables ready to be picked.

Mix and apply only the amount of pesticide you will need to complete the application. spray all the material according to label directions. Do not dispose of unused material by pouring down the drain or toilet. Do not pour on ground: soil or underground water supplies may be contaminated. follow label directions for disposing of container. Never burn pesticide containers.

PHYTOTOXICITY: Certain chemicals may cause plant injury if used at the wrong stage of plant development or when temperatures are too high. Injury may also result from excessive amounts or the wrong formulation or from mixing incompatible materials. Inert ingredients, such as wetters, spreaders, emulsifiers, diluents, and solvents, can cause plant injury. Since formulations are often changed by manufacturers, it is possible that plant injury may occur, even though no injury was noted in previous seasons.

Funding for this publication was made possible through a grant from the Elvenia J. Slosson Fund. 